Siniša Arsić

\title{
Key Factors of Project Success in Family Small and Medium-Sized Companies: the Theoretical Review
}

DOI: 10.7595/management.fon.2017.0013

\begin{abstract}
The paper proposes a systematization of the key success factors of projects, through the theoretical review of family-owned companies operating in the EU market. It is the small and medium companies that in their own way contribute to the overall success of the national economy in terms of economic activity, increased employment, development activities and defining better business environment. The theoretical review observed numerous studies of family businesses, and the contribution of this work is in the systematization of the results of previous research over three horizons, i.e., over the role of managers in the creation of successful projects (or owner if it is a family enterprise), institutional support for companies in Serbia and the EU, specific industries and the parent (regional) markets where a family company operates. Project management, as a general representation of the concept of implementation of strategic and operational endeavors, contains many specifics in terms of critical success factors of projects depending on the environment in which they are implemented. The goal of the paper is reflected in the identification and presentation of critical success factors of projects implemented in family companies. The paper concludes with a discussion of the research results in relation to the existing, similar research studies, as well as with the announcement of future research, which will examine the conclusions drawn on a real sample.
\end{abstract}

Keywords: factor, project, family company, industry, manager, owner

JEL : M10, M20, L20, O52

\section{Introduction}

Previous studies on the topic of project management in profit-oriented companies were based on a consideration of structure, a model of innovation, specific industry, as well as the possibilities of commercial exploitation of project results depending on the environment in which the project is performed. Very little research has been devoted to the differences (and similarities as well) between family and non-family companies, in terms of success factors that are crucial for the project to satisfy its stakeholders. It is possible, therefore, to define the main research question, and the answer to that question lies within the systematization of reviewed literature:

"Is the nature of project management in family companies different when compared to non-family companies?"

According to the results of previous research, the role of managers (the owner of the company, if it is a family company) is key to the success of the project, assuming delegated authority, optimal amount of resources available and the effects to be achieved by the implementation of the project.

The theoretical overview is based on studies that are the product of current global trends, and it must be noted that a narrowing of focus is present, and referring to the EU, and then to Serbia specifically. This is particularly reflected in the part of the paper dealing with institutional support for SMEs to do business in Serbia and the $\mathrm{EU}$, and in the comparative review and comparison of support for the family versus non-family companies. 
Certainly, it should be noted, that the specifics of the industry and the domestic market are also a very important perspective, perveived from the standpoint of project success factors of business changes which are applied in these markets and across different industries. The discussion of results attempts to identify similar conclusions, while the conclusion part of the paper sums up and announces the future research of the author.

\section{Key aspects of project success depending on perspective}

On the basis of the defined research question, it is possible to set the overall goal of the paper.

General goal: To define the specifics of CSF (critical success factors) of projects through the analysis of the criteria present in the family and non-family companies

while, for purposes of partial or complete closure of identified gaps in the existing literature, it is necessary to try to reach the specific objective of the paper:

- To focus aspects of project management which are unique only for the family company and to present the influence of "family variables" on success of projects which are implemented within those companies.

As previously announced, the systematization of the key aspects is determined by three perspectives (horizons), which follow below.

\subsection{The role of manager/owner in the process of creating project success}

Fortune and White (2006) state that the critical success factors of projects in general are the support of top management, the structure of defined objectives and the level of detail of project plans. Next, Kotlar et al. (2014) define that in the non-family companies the ability to bargain and to achieve compromise solutions is integrated into the objectives (criteria) of making profit, whereas in family companies this same ability represents a mechanism of control and power over individuals (usually the main authority is the owner himself).

The key success factors of projects in family companies are under the direct control of the owner of the family business (in the majority of analyzed companies, the owner is also the director of the family company). The main challenges of achieving success are influenced by the number of family employees, which are related to the owner, (un)defined hierarchy among family members of the owner and those who are not, as well as transparency in the vision of goals and personal motivation of owners and employees (Mihic et al., 2015). These conclusions have been supported by Alias et al. (2014), who outline human resources as the key factors to project success. Muller and Turner (2010) conclude that leadership attitude and intellectual competences of the owner/manager predetermine the success of projects, which in some cases contributes to large variances between project success and business success.

As critical factors / influences on the success of the projects (business activities) of the company, James (1999), Anderson and Reeb (2003), as well as Carney et al. (2017), outline the stability of the family firm in terms of structure, but also complement their conclusions with listing the presence of succession plans, and maximum utilization of resources. The advantages that the family company itself provides can be defined as:

- the stability of the workforce as a result of the stability of the family,

- overlapping financial resources of the family and the company,

- prevalence in a national economy which drives overall competitiveness,

- longer time horizon for achieving the goals.

In contrast to these conclusions, a study conducted by PwC (2014) points out the following key success factors of projects carried out by family companies - profitability and projects that are prioritized according to whether they provide long-term business contracts, while the stability of workplace for family members, as well as creating of new jobs are at the bottom of the priority list. Since the largest continuous internal challenge of preserving the family business is the need for constant innovation (products, processes, services), leading to shorter innovation cycles and shorter time for reaching the commercialization phase (time to market), are considered as the main criteria of success of the project.

Memili et al. (2010) conclude that the critical success factors of projects are planned in advance, according to the level of risk borne by the project itself, so as to ensure the target yield, as well as to maximize the potential of business that the project is implemented in. The main causes of low efficiency in the 
implementation of the main ideas of the project are the result of a smaller share of human resources in the process of generating ideas for innovation, as well as a lower percentage of employees who are generally able to implement the project (Liach \& Nordqvist, 2010). Conflicts often overlap with the priorities in the successful implementation of the projects, and they are a result of the parameters of the family (family stability, interpersonal relationships, the structure of the labour force, which is a derivative of family structure), which often interferes with the implementation of projects and the foundation of successful project management lies within total understanding and knowledge of these terms (Liu \& Low, 2010).

\subsection{Institutional support to SMEs in Serbia and in the EU}

Authors generally agree that the owners of family businesses are rather reluctant to take business risk when deciding on investments (resource allocation for a project), in cases where there is a large share of the family fortune invested in the company's capital (Sciascia et al., 2015). As a general conclusion, it can be noticed that family companies are looking for external sources of financing in order to successfully realize their ideas. Financing of commercial projects in the EU is regulated within programmes and projects for innovative activities as well as programmes supporting the competitiveness of small and medium-sized companies. According to research by the European Commission on improving the competitiveness of SMEs in the EU (European Commission Report, 2009), the findings are that $60 \%$ of all SMEs in the EU are family companies, producing $50 \%$ of all jobs. In Serbia, the SME sector generates about $30 \%$ of the total country's GDP (Minovic et al., 2016). Cruz and Letamendia (2010) supplemented with the following facts which are necessary for the understanding of policies of the EU countries in terms of institutional support:

- The largest share of family companies is present in Italy, France and Portugal;

- The capital of family companies is smaller than that of non-family companies, but on an average, the number of employees is similar;

- The life cycle length of family companies is on an average 60 years, while in non-family companies, the average life expectancy is 43 years (one-fifth of family-owned companies are older than a century);

- Investments in family projects provide better yields than those in non-family companies (since each euro invested in the family business is due to yield 3.5 euros, while in non-family companies it yields 2.4 euros);

- Th emarket risk within family businesses is lower than that in non-family businesses;

- Family companies create more jobs (employment growth rate is $3.4 \%$, compared to non-family companies where it is $0.8 \%$ ).

It should be noted that there are numerous funding programmes for projects of small and medium-sized companies (family and non-family), naming only the most important:

- Short-term and long-term loans of commercial banks;

- Horizon 2020 program Innovation (specific call SME Instrument);

- COSME program, etc.

Peters and Westerheide (2011) outline that family businesses most often decide in favour of short term credit funding of projects, since it enables them to get the desired investment funds in the quickest manner.Therefore, this presents the key precondition of project success which was originally imagined.

Serbia, as a candidate country for the EU membership, tends to cooperate with its European partners, to be able to reach the EU level of development. Individual initiatives and projects of family and non-family enterprises are all directed towards securing grants from the EU funds, and they are still very ill-coordinated and very seldom (having in mind the activity of certain EU countries, for instance Spain, Italy and Germany). It has to be noticed that the institutional support of the Republic of Serbia is still very inadequate (Szabo, 2013). Also, one must have in mind that the largest number of family companies in Serbia are still owned by their founders, and that the structure of business activities (projects) is still poor and susceptible to significant change.

\subsection{Specifics of the home (regional) market and industry}

In the last 10 years in Europe, the current trend is an increase in mergers and acquisitions, where the family businesses are increasingly directed to diversification of business activities (projects), unlike some previous times where the strategy was predominantly on the focus within a single industry (Defrancq et al., 2016). Erbetta et al. (2013) in their study state that there is a direct correlation between family ownership and company performance within specific industries and markets. Mihajlovic et al. (2011) assume that systematic decision making and project portfolio management efficiency are key (in any industry) to utilization of designed results of the project. 
Other authors complement the definition of these correlations, stating:

- Corruption is a greater threat to the family business, than to non-family companies (impact on the competitiveness on the domestic market is critical and is weakening the potential for growth of company sales) (Basetti et al., 2015);

- The perspective of regional development and structure of the family company has been affected by the direct impact on the regional economy development of individual markets (Stough et al., 2015);

- The processes of succession in family companies have different influences on the performance of the company, according to a survey covering 190 previous papers (Zahra \& Sharma, 2004; Chrisman et al., 2003);

- Marketing identity and positioning of the company as a family company, undoubtedly brings greater effects on the market, better commercialization of ideas, than in the case of non-family companies, according to a study covering 26 markets (Ernst \& Young, 2015);

- Innovation is in some cases directly sponsored and reciprocated by the top management of the family company, while within non-family companies that process is organized differently and realized within specific organizational units (Kellermans et al., 2012).

According to a research by Matijas (2015), the first phase of the life cycle of the family company takes between 15 and 25 years and in that period, there is a very large degree of deterioration of family companies. In different markets across the EU, notable failure rate is recognized within family businesses. Matijas argues that "in Spain from 80 to 90 percent of family businesses fail within the first five years of operation. At the European level, the number is quite high - 60 to 90 percent, while in the United States there is a slightly better situation."

Special attention should be paid to IT life cycle projects and related success factors, particularly in the area of family SMEs. Bjelica et al. (2015) revealed some of the general critical success factors in that area: clear business objectives, expertise, agile processes and proper stakeholder management.

It can be concluded that the phase of the life cycle of the family company is a very important if not the key factor in the success of projects, because all parameters and results depend primarily on that parameter. Several studies have looked at the individual stages of the life cycle:

- Growth phase is limited by the level of openness for innovative projects, and it is influenced by the choice of the right technology, as well as with the ability for quick meeting of customer needs and demands (Adebayo, 2014);

- Phase of success, stability, or maturity, is characterized by nine factors and those can be described as good infrastructure, optimal usage of resources, respect for legal regulations, adaptability to economic environment twists, international partnerships, social values, explorers' attitude, quality of human resources, financial conditions and support (Christen et al., 2013);

- Phase of decline is a direct result of the owner's incompetence to prioritize projects, and to effectively predict which projects to undertake (Ahmed \& Seet, 2009).

Rarely has any research integrally observed and clearly defined the life cycle stages of family SMEs, and what is more important, the purpose and application of understanding these phases, to achieve better business results. It certainly represents a gap which should be further explored.

PwC (2014), Banalieva et al. (2015), Fernandez Araoz et al. (2015), in their reports, discuss the main external challenges for family companies to succeed, outlining:

- Pricing competitiveness;

- Size of the market niche;

- General economic trends (significant amount of post-WWII newly founded companies in Europe are now facing their first change of generations);

- Poor talent management;

- Pro-market reforms of the transitioning economy.

Chaarani (2014) states that for the correct comparison of success criteria across different markets, it is necessary to bear in mind the cultural and economic situation of individual markets.Professionals / employees in the countries of South East Europe tend more easily to accept autocratic management styles, and are more willing to follow a project plan that has been developed by third parties. Contryry to this, professionals / employees in the Northern-European countries seek active participation in the planning of projects, and want a more active role in decision-making and planning of projects. Their colleagues from Sweden recognize the need for coordination, and are willing to follow a plan that has already been prepared, although they want to participate in its development. On the other hand, employees in Irish companies are very reluctant to imposed control and predefined goals (success criteria) (Turner et al., 2010). 


\section{Discussion of theoretical research results}

Success factors of projects defined in this study differ from success criteria defined in some other studies (Holt et al., 2016; Merino et al., 2015; Gallo et al., 2004). In these studies, major "outcomes" of family companies' business activities are measured through:

- The value of the portfolio of projects of a family business;

- Cohesion and emotional stability of the owner's family with family members who are employed in his company;

- Continuation of the business "tradition";

- Internationalization as a consequence of family experience and culture orientation;

- Image of the company and involvement in community activities.

It must be noted that there is a clear difference in the success rates of projects in the current literature that looks exclusively at family business and entrepreneurial ventures, compared to non-family companies (corporations).

In non-family companies, the success factors are:

- The financial performance of the project, the increase in market presence (Zellweger \& Sieger, 2012);

- Estimated attractiveness of innovation, which is estimated by the top management (Collins \& Reutzel, 2017);

- Entrepreneurial leadership, promotion of human and social capital, the growth of all performances in the market (Koryak et al., 2015);

- The correct perception of the environment, controlled ambitions of top management for business growth, greater flexibility and innovation, extensive use of private network of contacts (Hansen \& Hamilton, 2011);

- "Organic development", the internal expansion of the business, good company reputation (Jamieson et al., 2012),

- Appreciation of stakeholders, project personnel, contracting partners and main clients (Westerweld, 2003),

while, in family companies, project success is measured by:

- Appointment of a non-family professional to key management positions in the firm (Minichilli et al., 2015);

- Contribution to the long-term preservation of the family company and business, as well as a successful balance between financial and non-financial dimensions of business. (Zellweger \& Sieger, 2012);

- Owner's actions, ownership structure, age of the owner, and a proper understanding of the objectives and importance of the company for the family (Wallace, 2010);

- Quality relationships with other family companies, whether established by the owner of the family company as a "subsidiary" company (son of the owner is usually the owner of the subsidiary company) or are associated with another family company (Szabo, 2013).

It must be noted that some studies have dealt with the general review of the factors of success of small and medium-sized companies. So, Meister (2006) cites several key factors, from a well-defined mission of the project, up to the ability to properly resolve unexpected situations and deviations from the plan. At the same time, in the statistical report of the Enterprise Europe Network on a sample of 200 companies from EU countries, the following success factors can be distinguished:

- $83 \%$ of projects led to the successful establishment of contacts that are the basis for further research,

- $80 \%$ of companies have participated in more than one project and $76 \%$ of companies have performed projects related to the core business activities,

- half of the projects funded by the EU have led to new business contracts (business expansion). (EU Commission, 2016).

In addition to this, Todorovic et al. (2015) reveal the existence of correlation between knowledge transfer and more effective problem solving, as well as more efficient task schedule management. Xi et al. (2015) concludes that the quality of succession plans affects the continuity of the family business activities, therefore ongoing projects as well.

What is not deeply explored in the literature is the impact of the professionalization of staff upon the success of projects (a new model called the "family business"), and the extent to which non-family companies record better results as a consequence of a higher level of training and formal approach to work obligations. Also, there was no further research on how to find factors of project success in companies which do not have the ambition to grow, or maximize profit, because they simply want to stabilize their activities and remain in the stability zone as long as possible. 


\section{Conslusion}

The theoretical review concerning family and non-family business studies examined the role of managers in the creation and execution of successful projects, institutional support for companies in Serbia and the EU, and specific industries and the parent / regional markets in which a family company operates. The key contribution of this paper is the definition of key success factors of projects over these three horizons, whose specific combination and configuration requires a "light" model of project management, which should be organized around top management requirements as its primary purpose. The second most important precondition (for success) is to establish a proper support function in the process of realization of customer demands. The effectiveness and value of the model is crucial in assessing priorities among a number of projects, and this was noticed particularly in case of owners of family companies. Without a direct support of top management (family business owner), any measure of success is unnecessary because the project is not of interest to the company.

The paper clearly highlights the shortcomings of the existing literature, but there is also a fact that the business environment, in terms of family-owned companies, has not been explored fully in Serbia, nor were specific recommendations to support the operations of family-owned companies in Serbia initiated. Specific focus should be defined for IT industry projects, particularly in the family business segment, since there is a clear need for such a research.

The main limitation of this paper is the fact that it does not involve a real sample of projects and opinion of experts. Further expansion of this study concerns specific factors of success of projects in family companies in a particular market over the period of several years, including a real sample of companies and projects executed in Serbia and the EU region.

\section{REFERENCES}

[1] Alias, Z., Zawawi, E., Yusof, K., \& Aris, N.M. (2014). Determining Critical Success Factors of Project Management Practice: A Conceptual Framework.Procedia - Social and Behavioral Sciences, 153(16), 6169. https://doi.org/10.1016/j.sbspro.2014.10.041

[2] Adebayo, F.O. (2014). SME`s Growth and Open Innovation: Tackling SME`s Family Business Growth Challenges with Open Innovation, University of Jywaskyla, 1-102. Retrieved from: http://urn.fi/URN:NBN:fi:jyu-201411163267

[3] Ahmad, N.H., \& Seet, P.S. (2009). Dissecting Behaviors Associated with Business Failure: A Qualitative Study of SME Owners in Malaysia and Australia.Asian Social Science, 5(9), 98-104. DOI: http://dx.doi.org/10.5539/ass.v5n9p98

[4] Anderson, R.C., \& Reeb, D.M. (2003). Founding-Family Ownership and Firm Performance: Evidence from the S\&P 500.The Journal of Finance, 58(3), 1301-1328. http://www.jstor.org/stable/3094581

[5] Basetti, T., Dal Maso, L., \& Lattanzi, N. (2015). Family businesses in Eastern European countries: How informal payments affect exports. Journal of Family Business Strategy, 6(4), 219233.https://doi.org/10.1016/j.jfbs.2015.07.004

[6] Banalieva, E.R., Eddleston, K.A., \& Zellweger, T.M. (2015). When do family firms have an advantage in transitioning economies? Toward a dynamic institution-based view. Strategic Management Journal, 36, 1358-1377. DOI: $10.1002 / \mathrm{smj} .2288$

[7] Bjelica, D., Mihic, M., \& Toljaga-Nikolic, D. (2015). Theoretical perspective of it project management approaches, success factors and maturity models. Serbian Project Management Journal,5(2), 43-55. ISSN 2217-7256 (online)

[8] Carney, M., Duran, P., van Essen, M., \& Shapiro, D. (2017). Family firms, internationalization, and national competitiveness: Doesfamily firm prevalence matter?.Journal of Family Business Strategy, In Press, 1-14, DOI: $10.1016 / j . j f b s .2017 .06 .001$

[9] Chaarani, H. (2014). The success keys for family firms: Comparison between Lebanese and French systems. Lebanese Science Journal, 15(2), 133-150.

[10] Christen, A., Halter, F.A., Kammerlander, N., Kunzi, D., Merki, M., \& Zellweger, T.M. (2013). Success Factors for Swiss SMEs, University of St. Gallen, 1-42. Retrieved from https://www.alexandria.unisg.ch/223477/1/KMU-Studie_2013_EN.pdf

[11] Collins, J.D., \& Reutzel, C.R. (2017). The role of top managers in determining investment in innovation: The case of small and medium-sized enterprises in India.International Small Business Journal, 1-21. DOI: $10.1177 / 0266242616658507$

[12] Cruz, C., \& Letamendia, L.N. (2010). Value creation in listed European family firms, 1-21, IE Business School, Retrieved from: http://foreigners.textovirtual.com/empresasfamiliares/62/53818/ex_summary_english.pdf

[13] Chrisman, J.J., Chua, J.H., \& Sharma, P. (2003). Current trends and future directions in family business management studies: Toward a theory of the family firm. Coleman foundation,1-63. Retrieved from: http://citeseerx.ist.psu.edu/viewdoc/download?doi=10.1.1.134.43\&rep=rep1\&type =pdf 
[14] Defrancq, C., Huyghebaert, N., \& Luypaert, M. (2016). Influence of family ownership on the industrydiversifying nature of a firm's M\&A strategy: Empirical evidence from Continental Europe. Journal of Family Business Strategy, 7(4) ,210-226. DOI: 10.1016/j.jfbs.2016.11.002

[15] Ernst and Young study (2015). Staying power: how do family businesses create lasting success? Global survey of the world's largest family businesses. Kenesaw State University, 1-24. Retrieved from: https://familybusiness.ey-vx.com/pdfs/family-business-exec-summary.pdf

[16] Erbetta, F., Menozzi, A., Mazzola, P., Corbetta, G., \&Fraquelli, G. (2013). Assessing family firm performance using frontier analysis techniques: Evidence from Italian manufacturing industries. Journal of Family Business Strategy, 4(2),106-117. DOI: 10.1016/j.jfbs.2013.04.001

[17] European Commission Report (2009). Overview of family -business -relevant issues: research, networks, policy measures and existing studies, 1-33

[18] European Commission (2016). Research Survey. Retrieved from: http://www.brusselsnetwork.be/euregulations-m/786-90-of-smes-consider-their-participation-in-eu-funded-projects-a-success.html

[19] Fernandez-Araoz, C., Iqbal, S., \& Ritter, J. (2015). Leadership lessons from great family businesses. Harvard Business Review, 93(4), 82-88.

[20] Fortune, J., \&White, D. (2006). Framing of project critical success factors by a systems model. International Journal of Project Management, 24(1), 53-65. DOI: 10.1016/j.ijproman.2005.07.004

[21] Gallo, M.A., Tapies, J., \& Cappuyns, K. (2004). Comparison of Family and Nonfamily Business: Financial Logic and Personal Preferences. Family Business Review, 17(4), 303-318. DOI: 10.1111/j.17416248.2004.00020.x

[22] Hansen, B., \&Hamilton, R.T. (2011), Factors distinguishing small firm growers and nongrowers.International Small Business Journal, 29(3), 278-294. DOI: 10.1177/0266242610381846

[23] Holt, D.T., Pearson, A.W., Carr, J.C., \& Barnett, T. (2016). Family Firm(s) Outcomes Model: Structuring Financial and Nonfinancial Outcomes Across the Family and Firm.Family Business Review, 1-21. DOI: $10.1177 / 0894486516680930$

[24] James, H.J., (1999). Owner as Manager, Extended horizons and the family firm.International Journal of the Economics of Business, 6(1), 41-55. DOI: 10.1080/13571519984304

[25] Jamieson, D., Fettiplace, S., York, C., Lambourne, E., Bradford, P., \& Stone, I. (2012). Large Businesses and SMEs: Exploring how SMEs interact with large businesses, ORC International, London, 1-177. Retrieved from: https://www.gov.uk/government/uploads/system/uploads/attachment_data/file/34639/121196-exploring-how-smes-interact-with-large-businesses.pdf

[26] Kellermans, F., Eddleston, K., Sarathy, R., \& Murphy, F. (2012). Innovativeness in family firms - a family influence perspective.Small Business Economics, 38(1), 85-101. DOI: 10.1007/s11187-010-9268-5

[27] Kotlar, J., Fang, H., De Massis, A., \& Frattini, F. (2014): Profitability Goals, Control Goals, and the R\&D Investment Decisions of Family and Nonfamily Firms.Product Development\& Management Association, 31(6), 1-44. DOI: 10.1111/jpim.12165

[28] Koryak, O., Mole, K.F., Lockett, A., Hayton, J.C., Ucbasaran, D., \& Hodgkinson, G.P. (2015), Entrepreneurial leadership, capabilities and firm growth.International Small Business Journal, 33(1), 89-105. DOI: $10.1177 / 0266242614558315$

[29] Liach, J., \& Nordquist, M. (2010): Innovation in Family and Non-Family Businesses: A Resource Perspective.International Journal of Entrepreneurial Venturing, 2(3), 381-399. DOI: 10.1504/IJEV.2010.037119

[30] Liu, J.Y., \& Low, S.P. (2010). Work-family conflicts experienced by project managers in the Chinese construction industry.International Journal of Project Management, 29(2), 117-128. DOI: 10.1016/j.ijproman.2010.01.012

[31] Matijas, B. (2015). Three phases of family enterprise development, Journal Biznis, 47-50, Retrieved from: https://borismatijas.files.wordpress.com/2016/11/boris-matijas-112-biznis-magazin-web.pdf

[32] Memili, E., Eddleston, K.A., Kellermans, F.W., Zelwegger,\& T.M., \& Barnett, T. (2010). The critical path to family firm success through entrepreneurial risk taking and image.Journal of Family Business Strategy, 1(4), 200-209. DOI: 10.1016/j.jfbs.2010.10.005

[33] Meister, W. (2006). Successful project management for small to medium enterprises (SMEs), StrategyChange Management, Paper presented at PMI Global Congress 2006-Asia Pacific, Bangkok, Thailand. Newtown Square, PA: Project Management Institute, Retrieved from: http://www.pmi.org/learning/library/successful-pm-small-medium-enterprises-7631

[34] Merino, F., Monreal-Perez, J., \& Sanchez-Marin, G. (2015). Family SMEs' Internationalization: Disentangling the Influence of Familiness on Spanish Firms'Export Activity, Journal of Small Business Management, 53(4), 1164-1184, DOI: 10.1111/jsbm.12111

[35] Mihajlovic, I., Zivkovic, Z., Jovanovic, A., \& Madic, B. (2011). Investigating the level of project management concept implementation in some Serbian companies. Serbian Project Management Journal, 1(1), 39-54. ISSN 2217-7256 (online)

[36] Mihic, M., Arsic, S., \& Arsic, M. (2015). Impacts of entrepreneurs' stress and family memberson SMEs business success in Serbian family-owned firms. Journal for East European Management Studies, 4, $452-$ 483. DOI 10.1688/JEEMS-2015-04-Mihic 
[37] Minovic, J., Lazarevic-Moravcevic, M., \& Behara, I. (2016). Strategic Orientation of SMEs: Empirical Research. Management: Journal of Sustainable Business and Management Solutions in Emerging Economies, 21(81), 16-26. DOI: 10.7595/management.fon.2016.0026

[38] Minichilli, A., Nordqvist, M., Corbetta, G., \& Amore, M.D. (2015). CEO Succession Mechanisms, Organizational Context, and Performance: A Socio-Emotional WealthPerspective on Family-Controlled Firms. Journal of Management Studies, 51(7), 1153-1179, DOI: 10.1111/joms.12095

[39] Muller, R.J., \& Turner, R. (2010). Attitudes and leadership competences for project success. Baltic Journal of Management, 5(3), 307-329. DOI: 10.1108/17465261011079730

[40] Peters, B., \& Westerheide, P. (2011). Short term borrowing for long term projects: Are family businesses more susceptible to "irrational" financing choices? Centre for European Economic Research, 1-31. DOI:10.2139/ssrn.1342314

[41] Price Waterhouse Coopers Study (2014). Global Family Business Survey, 1-40, Retrieved from: http://www.pwc.com/gx/en/services/family-business/family-business-survey-2016/succession.html

[42] Sciascia, S., Nordquist, M., Mazzola, P., \& De Massis, A. (2015). Family Ownership and R\&D Intensity in Small- and Medium-Sized Firms.Journal of Product Innovation Management, 32(3), 349-360. DOI: 10.1111/jpim.12204

[43] Stough, R., Welter, F., Block, J., Wennberg, K., \& Basco, R. (2015). Family business and regional science: "Bridging the gap".Journal of Family Business Strategy, 6(4), 208-218. DOI:10.1016/j.jfbs.2015.11.002

[44] Szabo, A. (2013). Family Business and SMEs in the Black Sea economic cooperation region, Workshop report, Organization of the Black Sea Economic cooperation, Istanbul, ISBN: 978-605-4679-06-5

[45] Todorovic, M., Petrovic, D., Mihic, M., Obradovic, V., \& Bushuyev, S. (2015). Project success analysis framework: A knowledge-based approach in project management.International Journal of Project Management, 33(4), 772-783. DOI: 10.1016/j.ijproman.2014.10.009

[46] Turner, R., Ledwith, A., \& Kelly, J. (2010). Project management in small to medium-sized enterprises: Matching processes to the nature of the firm. International Journal of Project Management, 28, 744-755. DOI:10.1016/j.ijproman.2010.06.005

[47] Wallace, J.S. (2010). Family Owned Businesses: Determinants of Business Success and Profitability, All Graduate Theses and Dissertations, Utah State University, 1-94. Retrieved from: http://digitalcommons.usu.edu/cgi/viewcontent.cgi?article $=1590 \&$ context $=$ etd

[48] Westerweld, E. (2003). The Project Excellence Model: linking success criteria and critical success factors. International Journal of Project Management,21(6), 411-418. DOI: 10.1016/S0263-7863(02)00112-6

[49] Xi, J.M., Kraus, S., Filser, M., \& Kellermanns, F.W. (2015). Mapping the field of family business research:past trends and future directions.International Entrepreneurship and Management Journal, 11, 113-132, DOI: 10.1007/s11365-013-0286-z

[50] Zahra, S.A., \& Sharma, P. (2014). Family business research: A strategic reflection.International Family Enterprise Research Academy, 17(4), 331-346. DOI: 10.1111/j.1741-6248.2004.00022.x

[51] Zellweger, T., \& Sieger, P. (2012). Entrepreneurial Orientation in Long-lived Family Firms.Small Business Economics, 38(1), 67-84. DOI: 10.1007/s11187-010-9267-6

Received: 2017-07-13

Accepted: 2017-08-28

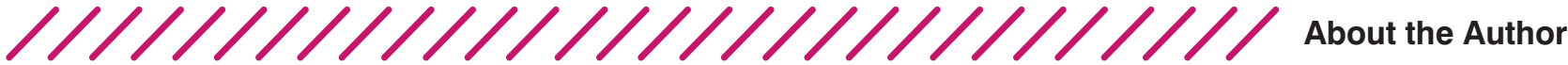

\author{
Siniša Arsić \\ Telekom Srbija \\ sinisaars@telekom.rs
}

Siniša Arsić is currently employed at the Telekom Srbija (since 2015), where he works as a product porfolio management associate for private mobile users. Also, he is a PhD student at the Faculty of Organizational Sciences, University of Belgrade, studying quantitative management at his $1^{\text {st }}$ year. His main research interests, and history of published papers, deal mainly with family businesses, project management and innovation management. In 2014 he took part in a research and innovation project,

which applied for EU Horizon 2020 funds under specific call named SME Instrument. The project proposal dealt with research innovation involving a Serbian SME, two Italian SMEs and a Slovenian research institute for quality and standardization. 